Article

\title{
Garlic (Allium sativum L.) Cultivation Using Vermicompost-Amended Soil as an Aspect of Sustainable Plant Production
}

\author{
Grzegorz Pączka ${ }^{1, *(\mathbb{D}}$, Anna Mazur-Pączka ${ }^{1}$, Mariola Garczyńska ${ }^{1}{ }^{(}$, Joanna Kostecka $^{1}$ and Kevin R. Butt $^{2}{ }^{2}$ \\ 1 Department of the Basis of Agriculture and Waste Management, Institute of Agricultural Sciences, \\ Land Management and Environmental Protection, College of Natural Sciences, University of Rzeszow, \\ Cwiklinskiej 1a, 35-601 Rzeszow, Poland; anamazur@ur.edu.pl (A.M.-P.); mgar@ur.edu.pl (M.G.); \\ jkosteck@ur.edu.pl (J.K.) \\ 2 Natural Sciences, University of Central Lancashire, Preston PR1 2HE, UK; krbutt@uclan.ac.uk \\ * Correspondence: grzegp@ur.edu.pl; Tel.: +48-17-872-1665
}

\section{check for} updates

Citation: Pączka, G.; Mazur-Pączka, A.; Garczyńska, M.; Kostecka, J.; Butt, K.R. Garlic (Allium satioum L.) Cultivation Using VermicompostAmended Soil as an Aspect of Sustainable Plant Production. Sustainability 2021, 13, 13557. https://doi.org/10.3390/ su132413557

Academic Editors: Helvi Heinonen-Tanski and Antoni Sánchez

Received: 15 October 2021

Accepted: 6 December 2021

Published: 8 December 2021

Publisher's Note: MDPI stays neutral with regard to jurisdictional claims in published maps and institutional affiliations.

Copyright: (c) 2021 by the authors. Licensee MDPI, Basel, Switzerland. This article is an open access article distributed under the terms and conditions of the Creative Commons Attribution (CC BY) license (https:/ / creativecommons.org/licenses/by/ $4.0 /)$.

\begin{abstract}
To achieve higher yields and maximum plant growth, excessive amounts of inorganic fertilisers are often applied to soils, affecting human and animal health and leading to the degradation of environmental resources. The use of organic fertilisers is proposed as an alternative to mineral fertilisation. One of the more frequently used organic fertilisers is vermicompost, which contains nutrients for plants in readily available forms and is characterised by the slow release of macronutrients and microelements into the soil environment. In a two-year field study, an attempt was made to use vermicompost produced from the waste mass of littoral plants as a soil amendment in the cultivation of garlic (Allium sativum). The experiment was conducted on raised beds with three treatments which were substitution of $10 \%, 25 \%$ and $50 \%$ vermicompost (V10, V25 and V50, respectively) to a heavy clay soil (SL), that with no addition acted as a control. Results showed that the $50 \%$ vermicompost addition had the most beneficial effect on selected (from a practical point of view) plant traits (e.g., diameter and mean bulb weight, mean number of cloves per bulb and mean clove weight, and mean yield), as well as on the content of macronutrients and microelements in garlic cloves. Lowest values of the analysed traits for A. sativum were found in the SL control group. No significant differences were found for the analysed parameters in the aboveground parts of plants in all the applied substrates.
\end{abstract}

Keywords: A. sativum; plant growth; plant nutrients; substrate construction; vermicompost

\section{Introduction}

Crop production strategy should be based on increasing soil productivity without compromising environmental quality and maintaining a balanced system of soil-plantenvironment linkages [1]. As reported by Stewart et al. [2] and Dauda et al. [3], excessive amounts of inorganic fertilisers are applied to soils to achieve higher yield and maximum plant growth value. When applied in their pure form without the addition of organic components, these fertilisers can adversely affect human and animal health and lead to the degradation of environmental resources [4].

In the last decade, urban agriculture, which is defined as the production of food (mainly crops) within a city or village, contributing to resources produced for the local community, has become increasingly common [5]. In addition to providing food, this local form of agriculture also offers benefits such as recycling and reusing organic waste and water [6]. To improve plant growth conditions and optimise the use of the often small, cultivated area, local farmers and gardeners often adopt raised bed crop production systems [7]. Raised beds are constructed above the ground surface, in the form of a frame made of various materials and filled with a growing substrate [8]. 
One of the world's twenty most important and frequently grown vegetables with high fertiliser requirements is garlic (A. sativum) [9]. According to the FAO [10], approximately 10 million tonnes of garlic are grown worldwide annually. It is estimated that production in Poland is maintained at a level of about 15-20 thousand tonnes and is carried out on an area of about 3 thousand hectares, mostly in home gardens, on small areas [11]. According to Sachin et al. [12], the prevalence of small-scale garlic cultivation has made it a more desirable crop production option to maximise qualitative and quantitative yield of bulbs per unit area rather than to increase the cultivated area. Worldwide, the economic importance of this spice crop has increased significantly in recent years. It has been shown that garlic has antibacterial and antiparasitic effects, strengthens the body's immunity, has a beneficial effect on maintaining normal levels of cholesterol and lipids in the blood, and shows anticancer effects [13]. Garlic and most species of the genus Allium have a low capacity to absorb nutrients from soils due to a relatively underdeveloped root system. Therefore, for proper plant development and high-quality yields, an adequate, balanced supply of readily available nutrients is essential in cultivating $A$. sativum [14]. One of the increasingly used organic fertilisers is vermicompost, which is characterised by the slow release of macronutrients and microelements into the soil environment. The elements it contains, such as nitrogen, phosphorus, potassium, calcium, and magnesium, are present in forms that are readily available to plants [15]. Vermicompost has a crumbly structure with high porosity, which promotes good aeration and high water holding capacity. This affects the quality of root systems in plants and the development of soil microflora and faunal activity that can affect the macronutrients and microelements content available to plants [16]. Vermicomposts also have great potential in maintaining soil fertility as they are a source of phytohormones such as auxins, gibberellins, and cytokinins $[17,18]$.

Organic fertilisers are an excellent alternative to mineral fertilisation. It was shown that fertilising garlic with wood ash and fermented manure produced garlic with low moisture content in the bulbs, high pungency, and higher mineral content [14]. The positive effect of manure compost on selected garlic traits (e.g., plant length, number of leaves, bulb weight, number of cloves and weight of cloves) was shown by Shafeek et al. [19]. Alternatively, Zaller [20] showed the positive effect of vermicompost on selected tomato traits (e.g., fruit firmness, glucose, and fructose content). Atiyeh et al. [21] showed that the addition of vermicompost to the substrate positively affected seed germination and plant seedling growth and development. According to Suthar [22], the application of vermicompost increases the growth and productivity of common wheat. Kale et al. [23] and Nethra et al. [24] showed positive effects of vermicompost on ornamental plants (Callistephus chinensis) where vermicompost at a dose of $10 \mathrm{t} \cdot \mathrm{ha}^{-1}$ had a positive effect on plant height, number of leaves and flowers. Kenea and Gedamu [25] argue that using good quality vermicompost for fertiliser purposes is crucial to increase plant productivity while minimising negative environmental impacts.

The aim of the present study was to evaluate the effects of using selected amounts of vermicompost, produced from waste mass of expansive littoral plants, as a soil additive in garlic (A. sativum L.) cultivation. A standard soil was used as a control with proportions of the vermicompost $(10,25$ and $50 \%)$ added as treatments. The objectives were to record the quantitative effects of these additions on properties of the garlic produced. Specifically, these were: (i) mean diameter and bulb weight, (ii) mean number of cloves per bulb and mean clove weight, (iii) mean yield, and (iv) the content of macronutrients and microelements in garlic cloves.

\section{Materials and Methods}

\subsection{Vermicompost Production from Littoral Plant Residues}

Vermicompost production was conducted according to the methodology proposed by Paczka et al. [26] in vermireactors constructed from plastic boxes with dimensions of $700 \mathrm{~mm} \times 450 \mathrm{~mm} \times 300 \mathrm{~mm}$ (length $\times$ width $\times$ height). Plant waste in the form of cleaned and shredded waste plant biomass (Iris pseudacorus L. and Ceratophyllum demersum 
L. in a 1:1 ratio) obtained during mowing and cleaning of the littoral zone of a dam reservoir was placed in the prepared vermireactors and only sexually mature earthworms (Eisenia fetida), with an initial total biomass of $5.0 \pm 0.5 \mathrm{~g} \mathrm{dm}^{-3}$ waste, were introduced. The vermireactors were protected from above with cardboard to prevent soil drying and nylon netting to prevent the escape of the earthworms. The vermicomposting process was conducted in an air-conditioned chamber at a temperature of $20 \pm 0.5^{\circ} \mathrm{C}$. To maintain the appropriate humidity inside the vermireactors, they were moistened with tap water every ten days. After completion of the vermicomposting process, the vermicompost was separated from the biomass of earthworms and cocoons and it was left (in a shaded place) for a period of one month.

\subsection{Experimental Design}

Effects of generated vermicompost on selected aspects of $A$. sativum were studied under field conditions using raised beds. Winter garlic of the Harnaś cv. obtained from the Department of Breeding and Seed Production POLAN constituted the plant material for the study. Four experimental combinations were established. These were a control group of standard agricultural soil (SL), plus 3 treatments where different proportions of vermicompost were added to the soil: V10 $=10 \%, \mathrm{~V} 25=25 \%$, V $50=50 \%$ of vermicompost, added to the soil.

The standard soil was collected from an area used for agricultural production located near Tyczyn (south-eastern Poland) and classified as heavy loam $(<0.02 \mathrm{~mm}$ fraction content-37.9\%) [27]. Vermicompost from waste of littoral plants was produced at the Institute of Agricultural Sciences, Land Management and Environmental Protection, University of Rzeszów. The content of macronutrients and microelements in the applied substrates is presented in Table 1.

Table 1. Content of macronutrients and microelements in the given growth media-details in text (mean \pm standard deviation based on five samples).

\begin{tabular}{|c|c|c|c|c|c|c|}
\hline Parameter. & Units & Soil (SL) & Vermicompost & V10 & V25 & V50 \\
\hline $\mathrm{C}$ & & $5207.1 \pm 98.4 \mathrm{a}$ & $72,556.7 \pm 2995.9 b$ & $12,133.4 \pm 541.1 \mathrm{c}$ & $22,897.4 \pm 772.3 \mathrm{~d}$ & $38,507.1 \pm 935.4 \mathrm{e}$ \\
\hline $\mathrm{N}$ & & $822.6 \pm 37.2 \mathrm{a}$ & $4792.3 \pm 99.6 \mathrm{~b}$ & $1189.9 \pm 41.8 \mathrm{c}$ & $1841.6 \pm 66.3 \mathrm{~d}$ & $2874.2 \pm 79.9 \mathrm{e}$ \\
\hline$P$ & & $98.9 \pm 11.3 \mathrm{a}$ & $3187.5 \pm 38.8 \mathrm{~b}$ & $410.4 \pm 19.7 c$ & $862.2 \pm 23.5 \mathrm{~d}$ & $1646.8 \pm 26.1 \mathrm{e}$ \\
\hline K & ఏ & $126.8 \pm 21.9 \mathrm{a}$ & $9972.7 \pm 311.3 b$ & $1132.7 \pm 62.2 \mathrm{c}$ & $2581.7 \pm 81.1 \mathrm{~d}$ & $5058.9 \pm 106.2 \mathrm{e}$ \\
\hline $\mathrm{Ca}$ & है & $688.1 \pm 30.5 \mathrm{a}$ & $36,337.1 \pm 2296.8 b$ & $4229.4 \pm 99.8 \mathrm{c}$ & $9619.4 \pm 322.7 \mathrm{~d}$ & $18,474.5 \pm 878.9 \mathrm{e}$ \\
\hline $\mathrm{Mg}$ & $T_{n 0}$ & $98.9 \pm 12.2 \mathrm{a}$ & $4986.2 \pm 211.7 b$ & $587.3 \pm 26.9 c$ & $1322.5 \pm 52.1 \mathrm{~d}$ & $2549.4 \pm 97.4 \mathrm{e}$ \\
\hline $\mathrm{Cu}$ & $\underline{60}$ & $11.4 \pm 2.2 \mathrm{a}$ & $24.9 \pm 3.3 b$ & $12.7 \pm 2.4 \mathrm{ac}$ & $14.8 \pm 2.5 c$ & $18.3 \pm 2.8 \mathrm{~d}$ \\
\hline $\mathrm{Mn}$ & జే & $479.3 \pm 25.1 \mathrm{a}$ & $4899.8 \pm 177.5 b$ & $925.1 \pm 36.3 c$ & $1586.7 \pm 50.1 \mathrm{~d}$ & $2687.2 \pm 87.7 \mathrm{e}$ \\
\hline $\mathrm{Zn}$ & & $66.9 \pm 7.4 \mathrm{a}$ & $131.4 \pm 11.7 \mathrm{~b}$ & $72.6 \pm 7.9 \mathrm{ac}$ & $82.4 \pm 9.2 c$ & $98.9 \pm 9.3 \mathrm{~d}$ \\
\hline $\mathrm{Cd}$ & & $1.1 \pm 0.1 \mathrm{a}$ & $0.15 \pm 0.0 \mathrm{~b}$ & $1.0 \pm 0.0 \mathrm{a}$ & $0.9 \pm 0.0 \mathrm{a}$ & $0.6 \pm 0.0 \mathrm{c}$ \\
\hline $\mathrm{Pb}$ & & $13.7 \pm 2.9 a$ & $1.1 \pm 0.2 \mathrm{~b}$ & $12.4 \pm 1.8 \mathrm{ac}$ & $10.6 \pm 1.5 c$ & $7.4 \pm 1.1 \mathrm{~d}$ \\
\hline $\mathrm{C} / \mathrm{N}$ ratio & - & $6.33 \pm 0.4 \mathrm{a}$ & $15.14 \pm 0.5 b$ & $10.2 \pm 0.8 c$ & $12.5 \pm 0.5 \mathrm{~d}$ & $13.4 \pm 0.5 \mathrm{~d}$ \\
\hline $\mathrm{pH}$ in $\mathrm{H}_{2} \mathrm{O}$ & - & $6.28 \pm 0.27 a$ & $6.41 \pm 0.02 \mathrm{a}$ & $6.32 \pm 0.2 \mathrm{a}$ & $6.35 \pm 0.1 \mathrm{a}$ & $6.36 \pm 0.1 \mathrm{a}$ \\
\hline $\begin{array}{c}\text { Electrical } \\
\text { conductivity }\end{array}$ & $\mathrm{ms} \cdot \mathrm{cm}^{-1}$ & $0.19 \pm 0.002 \mathrm{a}$ & $2.79 \pm 0.01 b$ & $0.77 \pm 0.01 \mathrm{c}$ & $1.41 \pm 0.01 \mathrm{~d}$ & $2.08 \pm 0.01 \mathrm{e}$ \\
\hline
\end{tabular}

Mean values in the same row followed by different letters are statistically different $(p<0.05)$.

Raised beds were constructed from wooden planks. They took the form of square frames measuring $100 \mathrm{~cm} \times 100 \mathrm{~cm} \times 30 \mathrm{~cm}$ (length $\times$ width $\times$ height), which were placed on a level, unshaded area $1 \mathrm{~m}$ from each other. The raised beds were filled with the treatment substrates (to a height of $27 \mathrm{~cm}$ ) prepared as specified. Healthy and uniform garlic cloves with an average weight of $3.5 \pm 0.1 \mathrm{~g}$ were selected and planted at a depth of $6 \mathrm{~cm}$, with a spacing of $25 \mathrm{~cm}$ between rows and $10 \mathrm{~cm}$ between plants, which in each replicate (each raised bed) gave three rows with eight plants in each. Growing plants were watered uniformly as required, at the same time keeping the substrate moist. No 
herbicides, fungicides, or chemical agents were introduced during cultivation, and manual weed control methods were used. The experiment was conducted twice: from 25 September 2018 (planting) to 4 July 2019 (harvest) and from 20 September 2019 (planting) to 6 July 2020 (harvest) near the town of Tyczyn (south-eastern Poland; $49^{\circ} 57.326^{\prime}$ N 22 $02.535^{\prime}$ E). In both seasons, plants grew in newly prepared media. Mean monthly temperature and mean monthly precipitation during the study period are presented in Figure 1a,b. The experiment was conducted in 5 replications for each combination.

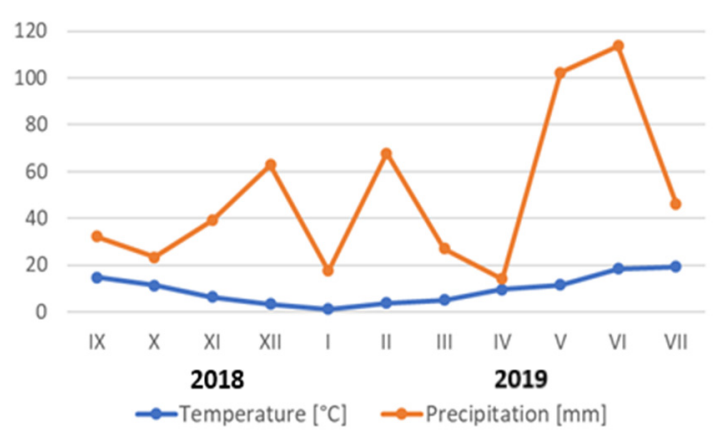

(a)

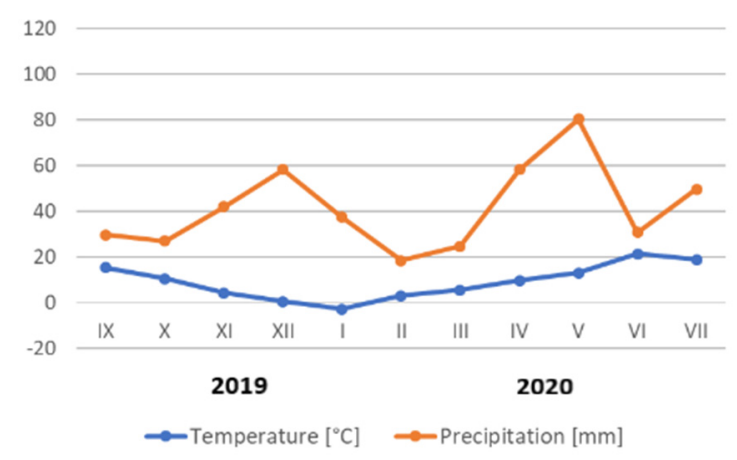

(b)

Figure 1. Distribution of mean monthly air temperatures and precipitation during the study period; (a) September 2018 to July 2019, (b) September 2019 to July 2020.

During the study period, plant survival analysis was carried out. At the end of the experiment, plants were selected and cleaned from the substrate by rinsing under running water, and then, after drying in filter paper, whole plants and their above- and belowground parts were measured and weighed. Then, samples of garlic cloves were subjected to physicochemical analysis to study the influence of the applied substrates on the content of selected macronutrients and microelements in their biomass.

\subsection{Physicochemical Analysis of Substrates and Plant Material}

The total content of macronutrients $(\mathrm{N}, \mathrm{P}, \mathrm{K}, \mathrm{Ca}, \mathrm{Mg})$ and microelements $(\mathrm{Cu}, \mathrm{Mn}, \mathrm{Zn}$, $\mathrm{Cd}, \mathrm{Pb}$ ) was determined in the growing substrate and plant material using the procedures described in Ostrowska et al. [28]. Nitrogen was determined by the Kjeldahl method using Kjeltec 8100 and 2006 Foss Tecator Digestor apparatus [28]. To determine other elements, the organic test material was subjected to hot mineralisation at $210^{\circ} \mathrm{C}$ in an open system in a mixture of concentrated mineral acids $\mathrm{HNO}_{3}: \mathrm{HClO}_{4}: \mathrm{H}_{2} \mathrm{SO}_{4}$ in a ratio of 20:5:1 (soil was mineralised in pure concentrated $\mathrm{HClO}_{4}$ ). Phosphorus was determined colourimetrically by the vanadium-molybdenum method on a Shimadzu UV-2600 spectrophotometer, while potassium, magnesium, calcium, and microelements and trace elements were determined by atomic absorption spectrophotometry using Hitachi Z-2000 [28]. Carbon was determined using a Vario EL-CUBE elemental analyser (from Elementar Analysensysteme $\mathrm{GmbH})$. The $\mathrm{pH}$ of the soil substrates was determined by the potentiometric method at a soil:water ratio of 1:2.5. Salt concentration was determined by the conductometric method. The $\mathrm{C} / \mathrm{N}$ ratio in the analysed substrates and plant biomass was calculated.

\subsection{Statistical Analysis}

All statistical analyses were expressed as the mean of five replicates using the computer software package Statistica 13.1. Tukey's $t$-test was used as a post hoc analysis to compare the means. One-way analysis of variance (ANOVA) was used to test for significant differences between treatments for the measured parameters and for significant differences between macronutrient and microelement contents. 


\section{Results and Discussion}

\subsection{Analysis of Selected Characteristics of A. satioum Relating to the Applied Growing Substrate}

The application of vermicompost as an organic fertiliser in garlic cultivation had a positive effect on selected (economically desirable) garlic traits: diameter and weight of bulbs, average number and weight of cloves and average yield (Table 2, Figure 2a-c).

Table 2. Selected plant features for the given treatment growth media (as in Table 1)—Mean \pm standard deviation based on five replicates).

\begin{tabular}{|c|c|c|c|c|c|}
\hline $\begin{array}{c}\text { Plant } \\
\text { Features }\end{array}$ & Year & SL & V10 & V25 & V50 \\
\hline \multirow{3}{*}{$\begin{array}{c}\text { plant } \\
\text { survivability } \\
{[\%]}\end{array}$} & 2019 & 82 & 82 & 85 & 85 \\
\hline & 2020 & 81 & 84 & 85 & 87 \\
\hline & Mean \pm sd & $82 \mathrm{a}$ & $83 \mathrm{a}$ & $85 \mathrm{a}$ & $86 a$ \\
\hline \multirow{3}{*}{$\begin{array}{l}\text { leaf length } \\
{[\mathrm{cm}]}\end{array}$} & 2019 & $33.2 \pm 1.46$ & $33.4 \pm 2.52$ & $34.3 \pm 2.44$ & $34.5 \pm 2.26$ \\
\hline & 2020 & $32.7 \pm 1.68$ & $33.6 \pm 2.27$ & $34.1 \pm 2.83$ & $34.3 \pm 2.40$ \\
\hline & Mean \pm sd & $32.9 \pm 1.52 \mathrm{a}$ & $33.4 \pm 2.48 \mathrm{a}$ & $34.2 \pm 2.69 \mathrm{a}$ & $34.4 \pm 2.35 \mathrm{a}$ \\
\hline \multirow{3}{*}{$\begin{array}{l}\text { leaf No. [per } \\
\text { plant] }\end{array}$} & 2019 & $7.1 \pm 0.25$ & $6.7 \pm 0.26$ & $7.1 \pm 0.22$ & $7.2 \pm 0.28$ \\
\hline & 2020 & $6.7 \pm 0.29$ & $6.8 \pm 0.33$ & $7.0 \pm 0.29$ & $7.1 \pm 0.37$ \\
\hline & Mean \pm sd & $6.9 \pm 0.28 \mathrm{a}$ & $6.8 \pm 0.31 \mathrm{a}$ & $7.1 \pm 0.26 \mathrm{a}$ & $7.2 \pm 0.34 \mathrm{a}$ \\
\hline \multirow{3}{*}{$\begin{array}{l}\text { leaf weight } \\
\text { per plant }[g]\end{array}$} & 2019 & $28.6 \pm 3.97$ & $28.4 \pm 3.66$ & $28.5 \pm 4.58$ & $27.4 \pm 3.31$ \\
\hline & 2020 & $27.9 \pm 3.24$ & $28.7 \pm 4.14$ & $27.8 \pm 4.42$ & $28.7 \pm 3.42$ \\
\hline & Mean \pm sd & $28.3 \pm 3.77 \mathrm{a}$ & $28.6 \pm 3.89 a$ & $28.2 \pm 4.53 \mathrm{a}$ & $28.1 \pm 3.38 \mathrm{a}$ \\
\hline \multirow{3}{*}{$\begin{array}{l}\text { diameter } \\
{[\mathrm{cm}]}\end{array}$} & 2019 & $3.9 \pm 0.09$ & $4.9 \pm 0.23$ & $5.3 \pm 0.11$ & $5.7 \pm 0.13$ \\
\hline & 2020 & $4.1 \pm 0.11$ & $4.8 \pm 0.19$ & $5.5 \pm 0.21$ & $5.6 \pm 0.12$ \\
\hline & Mean \pm sd & $4.0 \pm 0.09 \mathrm{a}$ & $4.9 \pm 0.22 \mathrm{~b}$ & $5.4 \pm 0.14 \mathrm{bc}$ & $5.7 \pm 0.12 c$ \\
\hline \multirow{3}{*}{$\begin{array}{l}\text { bulb weight } \\
{[\mathrm{g}]}\end{array}$} & 2019 & $28.6 \pm 0.63$ & $41.7 \pm 0.54$ & $44.9 \pm 0.41$ & $60.5 \pm 0.95$ \\
\hline & 2020 & $29.2 \pm 0.71$ & $39.3 \pm 0.40$ & $45.8 \pm 0.46$ & $59.2 \pm 0.83$ \\
\hline & Mean \pm sd & $28.9 \pm 0.66 \mathrm{a}$ & $40.5 \pm 0.48 b$ & $45.4 \pm 0.44 b$ & $59.9 \pm 0.91 c$ \\
\hline \multirow{3}{*}{$\begin{array}{l}\text { No. of cloves } \\
\text { [per bulb] }\end{array}$} & 2019 & $7.6 \pm 0.81$ & $8.3 \pm 1.24$ & $8.2 \pm 0.88$ & $9.9 \pm 1.73$ \\
\hline & 2020 & $7.9 \pm 0.87$ & $8.1 \pm 1.38$ & $8.2 \pm 0.82$ & $9.4 \pm 1.59$ \\
\hline & Mean \pm sd & $7.8 \pm 0.84 \mathrm{a}$ & $8.2 \pm 1.30 \mathrm{a}$ & $8.2 \pm 0.84 \mathrm{a}$ & $9.7 \pm 1.67 \mathrm{~b}$ \\
\hline \multirow{3}{*}{$\begin{array}{l}\text { mean weight } \\
\text { of cloves [g] }\end{array}$} & 2019 & $3.3 \pm 1.04$ & $4.5 \pm 1.17$ & $5.0 \pm 0.81$ & $4.8 \pm 1.39$ \\
\hline & 2020 & $3.3 \pm 1.09$ & $4.4 \pm 1.08$ & $5.2 \pm 0.88$ & $5.0 \pm 1.32$ \\
\hline & Mean \pm sd & $3.3 \pm 1.07 \mathrm{a}$ & $4.5 \pm 1.12 b$ & $5.1 \pm 0.84 b$ & $4.9 \pm 1.36 b$ \\
\hline \multirow{3}{*}{$\begin{array}{l}\text { mean yield } \\
{\left[\mathrm{kg} \cdot \mathrm{m}^{-2}\right]}\end{array}$} & 2019 & 0.56 & 0.82 & 0.92 & 1.23 \\
\hline & 2020 & 0.57 & 0.79 & 0.93 & 1.24 \\
\hline & Mean \pm sd & $0.57 \pm 0.05 \mathrm{a}$ & $0.81 \pm 0.06 b$ & $0.93 \pm 0.05 b$ & $1.24 \pm 0.09 c$ \\
\hline
\end{tabular}

Mean values in the same row followed by different letters are statistically different $(p<0.05)$.

Significant differences between the SL control group and the combinations with vermicompost were shown regarding mean yield (with the highest difference of $140 \%$ for $\mathrm{SL}<\mathrm{V} 50 ; p<0.05$ ) (Table 2). Kenea and Gedamu [25], while investigating the effect of vermicompost made from Lantana camara and Partinium hystrophorous with the addition of manure on selected garlic traits, showed that at increased vermicompost share from 0 to $7.5 \mathrm{tha}^{-1}$, the average fresh weight of garlic increased by $9.5 \%$ compared to the control, while a 3-fold increase in the vermicompost rate (from 2.5 to $7.5 \mathrm{t} \mathrm{ha}^{-1}$ ) resulted in a $20 \%$ increase in A. sativum yield. A similar trend was shown in the present study, finding that the average yield of $A$. sativum increased as the proportion of vermicompost in the growing medium increased $(\mathrm{V} 10<\mathrm{V} 25<\mathrm{V} 50)$ (Table 2). 
(a)

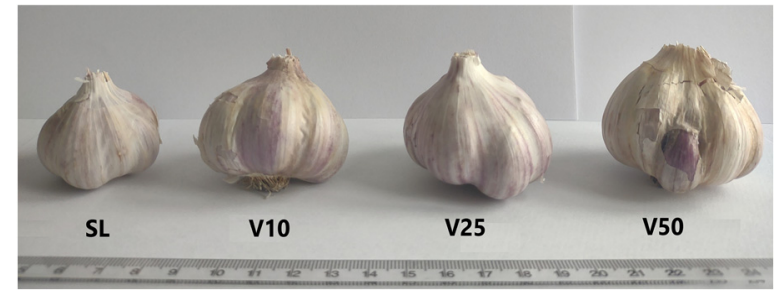

(b)

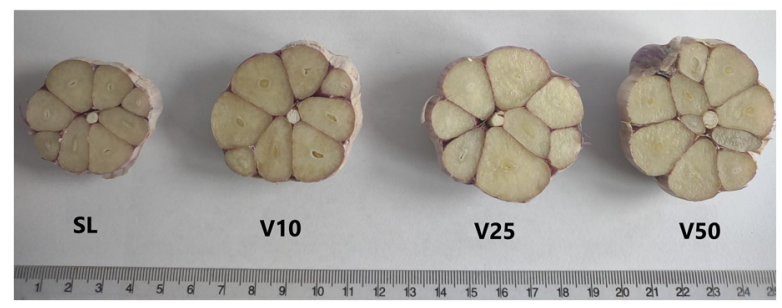

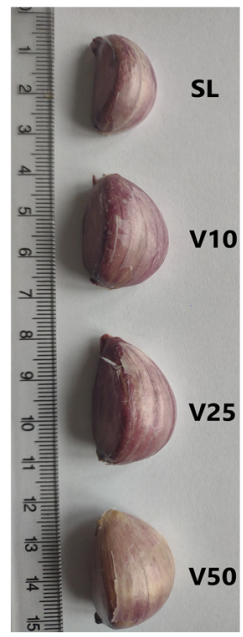

(c)

Figure 2. Average characteristics of A. sativum bulbs grown in the test substrates. (a) size and conformation of bulbs, (b) cross-section through bulbs, (c) size of individual cloves.

Sachin et al. [12], using vermicompost as the sole source of nitrogen in A. sativum fertilization, obtained a yield of $7.6 \mathrm{t} \mathrm{ha}^{-1}$ with an average bulb weight of $22.78 \mathrm{~g}$. The same authors also showed that the addition of organic manure as a source of nitrogen applied to soil had a more positive effect on the fresh weight and diameter of bulbs and the average number and weight of $A$. sativum cloves, compared to plant traits obtained when fertilised with vermicompost. On the other hand, the application of vermicompost had a positive effect on the storage effect of garlic. Diriba-Shiferaw et al. [29], growing garlic using inorganic fertilization, obtained a yield of $14.87 \mathrm{tha}^{-1}$, with an average bulb weight of $18.55 \mathrm{~g}$. Comparable results were obtained in the present study. Clark et al. [30] found that yields of tomato, maize, and beans in environmentally friendly crops were comparable with conventional crops. Although these authors showed that "organic" cultivation of crops on a larger scale could be problematic due to the costs associated with weed control, the expenses incurred were compensated by the premium crop prices obtained and the high demand for such products.

Garcia et al. [31] claim that vermicompost effectively reduces soil salinity and improves soil physical structure, both in laboratory and field experiments, and Aracon et al. [32] presented the positive effects of vermicompost addition on selected biological and chemical properties of soil. They showed that an increase in microbial activity positively affected the rate of nutrient cycling, the production of materials regulating plant growth, and increased their resistance and tolerance to pathogens. Tomati et al. [33] showed a high abundance of bacteria, actinomycetes, and fungi, and a high concentration of plant hormones, such as gibberellins, cytokinins, and auxins in sludge processed by earthworms. Thus, the higher trait values of garlic bulbs grown here, in V10, V25 and V50 may have been influenced by various factors, which include the slow and steady release of readily available nutrients characteristic of vermicomposts during plant growth and increased biological activity, which consequently led to adequate crop nutrition [34,35]. As reported by Phor et al. [36] and Alam et al. [37], the availability of $\mathrm{Zn}$ with $\mathrm{N}$ and $\mathrm{P}$ also plays a vital role in the growth of onion and garlic plants. Zinc deficiency resulted in growth inhibition, while higher content of this element increased onion yield by $29 \%$ compared to control. In the present study, the highest yield of garlic was obtained in the substrate with $50 \%$ addition of vermicompost (V50), where the contents of $\mathrm{Zn}, \mathrm{N}$ and $\mathrm{P}$ were $98.9 \pm 9.3 \mathrm{mg} \mathrm{kg}^{-1}$, $2874.2 \pm 79.9 \mathrm{mg} \mathrm{kg}^{-1}, 1646.8 \pm 26.1 \mathrm{mg} \mathrm{kg}^{-1}$ (Table 1$)$ and were significantly $(p<0.05)$ higher compared to the SL control group by $250 \%, 1560 \%$ and $48 \%$, respectively (Table 2 ). According to Nori et al. [38], nitrogen is essential to increase the yield and quality of garlic. However, these authors showed that $\mathrm{N}$ levels below $200 \mathrm{~kg}^{-1}$ increased the average number and weight of cloves and the weight and diameter of bulbs, while at higher $\mathrm{N}$ 
levels $\left(300 \mathrm{~kg} \mathrm{ha}^{-1}\right)$, the yield of bulbs decreased in favour of increasing the length and number of leaves. Phosphorus, in turn, is involved in every phase of plant cell growth. In agriculture and horticulture, $\mathrm{P}$ is essential in nutrient management to achieve maximum yields $[39,40]$.

In the present study, some differences in plant survival rates were observed between the crop groups, but they were not significant. However, this non-significant difference with other A. sativum bulb traits (Table 2) was manifested in significant differences in yield obtained (Table 2). Non-significant differences between groups were also shown for mean leaf length, number, and weight (with mean differences between SL and groups with vermicompost addition of $3.3 \%, 1.8 \%$ and $0.7 \%$, respectively; $p>0.05$ ) (Table 2). Sachin et al. [12], conducting a study on the effect of nitrogen from organic and inorganic fertilization on selected garlic traits, showed significant differences in plant height and the number of leaves (per plant) between experimental groups. In contrast, Diriba-Shiferaw et al. [41], using different multi-nutrient fertilisers in garlic cultivation, did not show evident differences in the number of leaves produced by the plants but found significant differences in their length. Similarly, Suthar [42], using vermicompost produced from crop residues with cow manure in the cultivation of $A$. sativum, showed that an increase in vermicompost dose affected the average leaf length but had no effect on the number of leaves per plant. Alemu et al. [43], as a result of fertilizing garlic with vermicompost produced from plant waste and cow manure, also showed no effect of vermicompost dose on the number of leaves, whilst inorganic nitrogen application led to significant differences.

It should be noted that although winter garlic is characterised by high adaptability to local growing conditions [44], the weight of bulbs produced, and the yield, can be significantly affected by climatic conditions [45]. Our results showed that climatic conditions from both growth periods (2018/2019 and 2019/2020) (Figure 1) did not significantly affect the selected traits of A. sativum (Table 2).

\subsection{Analysis of Vermicompost Treatments on the Content of Selected Macronutrients and Microelements in the Biomass of A. sativum Bulbs}

As shown in Table 3, the content of macronutrients and microelements in garlic cloves differed depending on the applied treatment. Significant differences were found in the content of the analysed elements between plants grown in the control SL substrate and $A$. sativum grown in combinations with vermicompost (the exception was the content of $\mathrm{Cd}$, where no significant differences were found between the treatments) (Table 3).

Table 3. Contents of macro and microelements $\left(\mathrm{mg} \mathrm{kg}^{-1}(\mathrm{dm})\right.$ ) in biomass of A. sativum bulbs (mean \pm standard deviation based on two test seasons (2018/2019 and 2019/2020) and five replicates for each experiment).

\begin{tabular}{ccccc}
\hline Parameter & Soil (SL) & V10 & V25 & V50 \\
\hline $\mathrm{N}$ & $20,124.2 \pm 25.4 \mathrm{a}$ & $23,608.5 \pm 23.1 \mathrm{~b}$ & $24,759.1 \pm 21.8 \mathrm{~b}$ & $28,155.2 \pm 19.3 \mathrm{c}$ \\
$\mathrm{P}$ & $2741.5 \pm 11.8 \mathrm{a}$ & $3562.3 \pm 11.4 \mathrm{~b}$ & $4411.8 \pm 13.5 \mathrm{c}$ & $5199.2 \pm 11.2 \mathrm{~d}$ \\
$\mathrm{~K}$ & $17,433.8 \pm 10.3 \mathrm{a}$ & $20,489.2 \pm 12.6 \mathrm{~b}$ & $20,952.1 \pm 11.9 \mathrm{~b}$ & $23,499.6 \pm 10.1 \mathrm{c}$ \\
$\mathrm{Ca}$ & $3140.2 \pm 21.2 \mathrm{a}$ & $5961.4 \pm 10.7 \mathrm{~b}$ & $7226.1 \pm 10.4 \mathrm{c}$ & $7288.5 \pm 11.5 \mathrm{c}$ \\
$\mathrm{Mg}$ & $670.8 \pm 11.1 \mathrm{a}$ & $856.3 \pm 10.3 \mathrm{~b}$ & $891.2 \pm 11.2 \mathrm{~b}$ & $903.9 \pm 10.9 \mathrm{~b}$ \\
$\mathrm{Cu}$ & $6.1 \pm 0.2 \mathrm{a}$ & $7.5 \pm 0.2 \mathrm{~b}$ & $7.8 \pm 0.1 \mathrm{~b}$ & $7.8 \pm 0.1 \mathrm{~b}$ \\
$\mathrm{Mn}$ & $8.5 \pm 0.2 \mathrm{a}$ & $10.6 \pm 0.2 \mathrm{~b}$ & $12.1 \pm 0.1 \mathrm{c}$ & $12.5 \pm 0.2 \mathrm{c}$ \\
$\mathrm{Zn}$ & $27.1 \pm 2.3 \mathrm{a}$ & $35.5 \pm 1.5 \mathrm{~b}$ & $36.1 \pm 1.2 \mathrm{~b}$ & $38.4 \pm 1.5 \mathrm{~b}$ \\
$\mathrm{Cd}$ & $0.5 \pm 0.1 \mathrm{a}$ & $0.4 \pm 0.0 \mathrm{a}$ & $0.4 \pm 0.0 \mathrm{a}$ & $0.4 \pm 0.1 \mathrm{a}$ \\
$\mathrm{Pb}$ & $3.84 \pm 0.1 \mathrm{a}$ & $2.61 \pm 0.1 \mathrm{~b}$ & $2.55 \pm 0.0 \mathrm{~b}$ & $2.27 \pm 0.0 \mathrm{~b}$ \\
\hline
\end{tabular}

Values followed by different letters in the same row are statistically different $(p<0.05)$.

Most elements' highest content among vermicompost treatments was in plants grown in 50\% vermicompost addition (V50). The V50 group was characterised by a significantly higher content of N, P, K as compared to the V10 and V25 groups (difference of $17 \%, 32 \%$ and $14 \%$ on average, respectively; $p<0.05$ ) and to the SL control (difference of $40 \%, 90 \%$ 
and $35 \%$ on average, respectively; $p<0.05$ ) (Table 3). Ca and Mn contents were found to be similar in plants grown in V25 and V50 treatments but, on average, were significantly higher relative to SL and V10 groups (131\% and 22\% difference, respectively; $p<0.05)$. No significant differences were observed regarding the contents of $\mathrm{Mg}, \mathrm{Cu}, \mathrm{Zn}$, and $\mathrm{Pb}$ in plants grown in treatments with different proportions of vermicompost (Table 3).

Described differences in macronutrient and microelement contents in garlic biomass were likely caused by a higher nutrient content available to plants in substrates with a higher proportion of vermicompost (Table 1). Barker and Pilbeam [46] reported that a good supply of nitrogen stimulates plant root growth and development and uptake of other nutrients, while phosphorus improves vegetable quality. According to Liu et al. [47], in the genus Allium, nitrogen and sulphur interactions are also important, as they can affect quality of the yield obtained (mainly flavour). As shown by these authors, inadequate $\mathrm{N}$ and $S$ reduced the flavour pungency of several onion cultivars. Coolong and Randle [48] showed that $\mathrm{N}$ and $\mathrm{S}$ deficiencies reduced the amount of flavour components in onions. In the present study, sulphur was not considered in the analysis of macronutrients and microelements contained in soil and biomass of garlic bulbs, as the taste qualities of these plants were not analysed.

Rizk et al. [49] showed that the application of $N$ and $P$ fertilization at 90 and $45 \mathrm{~kg} \mathrm{ha}^{-1}$ resulted in the highest content of $\mathrm{N}, \mathrm{P}$ and $\mathrm{K}$ in onion bulbs, compared to lower fertilization rates. Bull et al. [50] reported that the increase in phosphorus content in garlic leaves was significantly higher on sandy soils than on clay soils. These authors also stated that due to the low mobility of $\mathrm{P}$ in soil, its position relating to roots had a significant influence on uptake by plants, especially in soils with extreme P deficiency. In the present study, plants in the control group (with the lowest $\mathrm{P}$ content in biomass) grew in heavy clay soil, while the different proportions of vermicompost in the V10, V25 and V50 groups not only provided a uniformly distributed, different (treatment-specific; Table 1) phosphorus content to the soil but also changed the structure of the clay soil to a different extent. Vadala et al. [51] showed ranges of $\mathrm{K}$ 5920-7041 $\mathrm{mg} \mathrm{kg}^{-1}$, Ca $1723-1823 \mathrm{mg} \mathrm{kg}^{-1}$, and $\mathrm{Zn} \mathrm{15.31-18.84} \mathrm{mg} \mathrm{kg}^{-1}$, in garlic bulbs grown in different regions of Italy, which does not coincide with the results of the present study, since all treatments obtained higher elemental contents in the

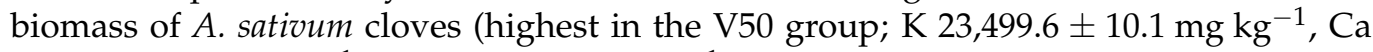
$7288.5 \pm 11.5 \mathrm{mg} \mathrm{kg}^{-1}, \mathrm{Zn} 38.4 \pm 1.5 \mathrm{mg} \mathrm{kg}^{-1}$ ) (Table 3). The accumulation of $\mathrm{K}$ by crop plants is greater than that of any other soil mineral, except for nitrogen in some species. Potassium is responsible for many physiological functions in plants. It helps in $\mathrm{pH}$ stabilisation and ionic regulation and is essential in plant water management [52]. K also increases plant resistance to diseases and parasites [53]. As confirmed by Vadala et al. [51], the use of appropriate fertilization can have a significant effect on selected garlic traits. A study by Diriba-Shiferaw et al. [54] admittedly showed that supplementary fertilization could significantly affect the chemical composition of garlic bulb, but only inorganic fertilisers were used in the cultivation of $A$. sativum. The study by Yoldas et al. [55] showed that organic fertilization in manure can play a significant role in obtaining good quantitative and qualitative garlic trait values.

\section{Conclusions}

The present study was conducted to verify whether the quantitative addition of vermicompost, produced from the waste mass of littoral plants, to mineral soil classified as heavy clay, would affect selected garlic traits and the content of macronutrients and microelements in their storage organs. From the results obtained, it can be concluded that the applied treatments had no significant effect on plant survival and the analysed parameters of the aboveground parts of $A$. sativum, i.e., the length, number, and weight of leaves. However, plants grown in substrates with the addition of vermicompost V10, V25 and V50 were characterised by significantly higher values of the analysed traits of the bulbs/cloves compared to the SL control group. The most favourable research result was shown for the cultivation combination with $50 \%$ addition of vermicompost to the soil 
(V50). This group included plants with significantly $(p<0.05)$ higher numbers of cloves per bulb and bulb weight which, combined with the highest survival rate $(p>0.05)$, gave the highest yield of $1.24 \pm 0.091 \mathrm{~kg} \mathrm{~m}^{-2}, 118 \%(p<0.05)$ higher than the SL control and, on average, $43 \%(p<0.05)$ higher than V10 and V25. The V50 group also produced plants with significantly $(p<0.05)$ higher $\mathrm{N}, \mathrm{P}$ and $\mathrm{K}$ content in cloves. It is concluded that littoral plant vermicompost can be used in horticulture or agriculture to grow plants to provide nutrients and improve the structure and properties of local mineral soils.

Author Contributions: Conceptualization, G.P.; methodology, G.P.; investigation, G.P., A.M.-P., M.G., J.K., K.R.B.; data curation, A.M.-P. and M.G.; writing-original draft preparation, G.P.; writing-review and editing, G.P., J.K. and K.R.B. All authors have read and agreed to the published version of the manuscript.

Funding: This research received no external funding.

Institutional Review Board Statement: Not applicable.

Informed Consent Statement: Not applicable.

Data Availability Statement: The data presented in this study are available on request from the corresponding author.

Conflicts of Interest: The authors declare no conflict of interest.

\section{References}

1. Ayala, S.; Prakasa Rao, E.V.S. Perspectives of soil fertility management with a focus on fertilizer use for crop productivity. Curr. Sci. 2002, 82, 797-807.

2. Stewart, W.M.; Dibb, D.W.; Johnston, A.E.; Smyth, T.J. The Contribution of Commercial Fertilizer Nutrients to Food Production. Agron. J. 2005, 97, 1-6. [CrossRef]

3. Dauda, S.N.; Ajayi, F.A.; Ndor, E. Growth and yield of water melon (Citrullus lanatus) as affected by poultry manure application. J. Agric. Soc. Sci. 2008, 4, 121-124.

4. Arisha, H.M.; Bradisi, A. Effect of mineral fertilizers and organic fertilizers on growth, yieldand quality of potato under sandy soil conditions. Zagazig J. Agric. Res. 1999, 26, 391-405.

5. Mougeot, L.J.A. Urban Agriculture: Definition, Presence, Potentials and Risks, and Policy Challenges; Cities Feeding People Series Report 31; International Development Research Centre: Ottawa, ON, Canada, 2000; pp. 1-58.

6. Mok, H.-F.; Williamson, V.G.; Grove, J.R.; Burry, K.; Barker, S.F.; Hamilton, A.J. Strawberry fields forever? Urban agriculture in developed countries: A review. Agron. Sustain. Dev. 2014, 34, 21-43. [CrossRef]

7. Sullivan, C.; Hallaran, T.; Sogorka, G.; Weinkle, K. An evaluation of conventional and subirrigated planters for urban agriculture: Supporting evidence. Renew. Agric. Food Syst. 2015, 30, 55-63. [CrossRef]

8. Cudnik, J.L. Evaluation of Substrates in Constructed, Raised Beds for Vegetable Culture. Master's Thesis, University of Georgia, Athens, Greece, 2014. Available online: https:/ / getd.libs.uga.edu/pdfs/cudnik_jessica_1_201405_ms.pdf (accessed on 19 July 2021).

9. Kopeć, A.; Piątkowska, E.; Leszczyńska, T.; Sikora, E. Healthy properties of garlic. Curr. Nutr. Food Sci. 2013, 9, 59-64.

10. FAOSTAT. Food and Agriculture Organization of the United Nations. Available online: http://faostat3.fao.org/browse/O/OC/E (accessed on 25 July 2021).

11. Olas-Sochacka, M. Common Garlic (Allium sativum L.); Institute of Horticulture: Skierniewice, Poland, 2016; pp. 1-4. (In Polish)

12. Sachin, A.J.; Bhalerao, P.P.; Patil, S.J. Effect of organic and inorganic sources of nitrogen on growth and yield of garlic (Allium sativum L.) var. GG-4. Int. J. Chem. Stud. 2017, 5, 559-562.

13. Grajek, W. The role of antioxidants in reducing the risk of cancer and cardiovascular disease. Żywność. Nauka. Technologia. Jakość 2004, 1, 3-11. (In Polish)

14. Babatunde, E.F.; Mofoke, E.A.L.; Udom, G.N.; Mohammed, G.U. Influence of Nutrient Source on the Elemantal Composition of Irrigated Garlic. AgroSci 2009, 8, 45-50. [CrossRef]

15. Talashilkar, S.C.; Bhangarath, P.P.; Mehta, V.B. Changes in chemical properties during composting of organic residues as influenced by earthworm activity. J. Indian Soc. Soil Sci. 1999, 47, 50-53.

16. Edwards, C.A.; Burrows, I. The potential of earthworms composts as plant growth media. In Earthworms in Waste and Environmental Management; Edwards, C.A., Neuhauser, E.F., Eds.; SPB Academic Publishing: The Hague, The Netherlands, 1988 ; pp. 21-32.

17. Grapelli, A.; Tomati, U.; Galli, E.; Vergari, B. Earthworm casting in plant propagation. HortScience 1985, 20, 874-876.

18. Tomati, U.; Galli, E.; Grappelli, A.; Dihena, G. Effect of earthworm casts on protein synthesis in radish (Raphanus sativum) and lettuce (Lactuca sativa) seedlings. Biol. Fertil. Soils 1990, 9, 288-289. [CrossRef] 
19. Shafeek, M.R.; Ali, A.H.; Mahmoud, A.R.; Hafez, M.M.; Rizk, F.A. Improving growth and productivity of garlic plants (Allium sativum L.) as affected by the addition of organic manure and humic acid levels in sandy soil conditions. . Int. J. Curr. Microbiol. Appl. Sci. 2015, 4, 644-656.

20. Zaller, J.G. Vermicompost in seedling potting media can affect germination, biomass allocation, yields and fruit quality of three tomato varieties. Eur. J. Soil Biol. 2007, 43, S332-S336. [CrossRef]

21. Atiyeh, R.; Edwards, C.; Subler, S.; Metzger, J. Pig manure vermicompost as a component of a horticultural bedding plant medium: Effects on physicochemical properties and plant growth. Bioresour. Technol. 2001, 78, 11-20. [CrossRef]

22. Suthar, S. Effect of vermicompost and inorganic fertilizer on wheat (Triticum aesticum) production. Nat. Environ. Pollut. Technol. 2006, 5, 197-201.

23. Kale, R.D.; Bano, K.; Sreenivasa, M.N.; Bagyaraj, D.J. Influence of worm cast on the growth and mycorrhizal colonization of two ornamental plants. South Indian Hortic. 1987, 35, 433-437.

24. Nethra, N.N.; Jayaprasad, K.V.; Kale, R.D. China aster (Callistephus chinensis (L.) Ness) cultivation using vermicompost as organic amendment. Crop. Res. 1999, 17, 209-215.

25. Fikru, T.K.; Fikreyohannes, G. Effect of vermicompost on growth, quality and economic return of garlic (Allium sativum L.) at Haramaya District, Eastern Ethiopia. Afr. J. Agric. Res. 2019, 14, 2159-2167. [CrossRef]

26. Pączka, G.; Mazur-Pączka, A.; Garczyńska, M.; Podolak, A.; Szura, R.; Butt, K.R.; Kostecka, J. Using Earthworms Eisenia fetida (Sav.) for Utilization of Expansive Littoral Plants Biomass. Appl. Sci. 2019, 9, 3635. [CrossRef]

27. Polish Norm PN-R-04033 1998: Mineral Soils. Classification; Polish Committee for Standardization: Warsaw, Poland, 1998; pp. 1-5. (In Polish)

28. Ostrowska, A.; Gawliński, S.; Szczubiałka, Z. The Soil and Plants Method of Analysis and Evaluation; IOŚ Publishing: Warsaw, Poland, 1991; p. 334. (In Polish)

29. Diriba-Shiferaw, G.; Nigussie-Dechassa, R.; Woldetsadik, K.; Tabor, G.; Sharma, J. Effect of Nitrogen, Phosphorus, and Sulphur Fertilizers on Growth Yield, and Economic Returns of Garlic (Allium sativum L.). Sci. Technol. Arts Res. J. 2016, 4, 10. [CrossRef]

30. Clark, S.; Klonsky, K.; Livingston, P.; Temple, S. Crop-yield and economic comparisons of organic, low-input, and conventional farming systems in California's Sacramento Valley. Am. J. Altern. Agric. 1999, 14, 109-121. [CrossRef]

31. García, C.; Ceccanti, B.; Masciandaro, G.; Hernández, T. Phosphatase and $\beta$-glucosidase activities in humic substances from animal wastes. Bioresour. Technol. 1995, 53, 79-87. [CrossRef]

32. Arancon, N.; Edwards, C.; Bierman, P. Influences of vermicomposts on field strawberries: Part 2. Effects on soil microbiological and chemical properties. Bioresour. Technol. 2006, 97, 831-840. [CrossRef]

33. Tomati, U.; Grappelli, A.; Galli, E. The presence of growth regulators in earthworm-worked wastes. In On Earthworms, Proceeding of The International Symposium on Earthworms. Selected Symposia and Monographs. Unione Zoologica Italiana, Bologna-Carpi, Italy, 31 March-4 April 1985; Bonvicini Paglioi, A.M., Omodeo, P., Eds.; Mucchi: Modena, Italy, 1987; Volume 2, pp. $423-436$.

34. Patil, M.B.; Shitole, D.S.; Purandare, N.D. Response of garlic to organic and inorganic fertilizers. J. Hortic. Sci. $2007,2,130-133$.

35. Nainwal, R.C.; Singh, D.; Katiyar, R.S.; Sharma, L.; Tewari, S.K. Response of garlic to integrated nutrient management practices in a sodic soil of Uttar Pradesh, India. J. Spices Aromat. Crop. 2015, 24, 33-36.

36. Phor, S.K.; Pandey, U.C.; Verma, U. Effects of zinc on the growth and yield of garlic (Allium sativum L). Crop. Res. 1995, 9, $286-291$.

37. Alam, M.N.; Abedin, M.J.; Azad, M.A.K. Effect of micronutrients on growth and yield of onion under calcareous soil environment. Int. Res. J. Plant Sci. 2010, 1, 56-61.

38. Nori, M.; Bayat, F.; Esmaeili, A. Changes of vegetative growth indices and yield of garlic (Allium sativum L.) in different sources and levels of nitrogen fertilizer. Int. J. Agric. Crop. Sci. 2012, 4, 1394-1400.

39. Grant, C.A.; Flaten, D.N.; Tomasiewicz, D.J.; Sheppard, S.C. The importance of early season phosphorus nutrition. Can. J. Plant Sci. 2001, 81, 211-224. [CrossRef]

40. Hopkins, B.G.; Horneck, D.A.; MacGuidwin, A.E. Improving Phosphorus Use Efficiency Through Potato Rhizosphere Modification and Extension. Am. J. Potato Res. 2014, 91, 161-174. [CrossRef]

41. Diriba-Shiferaw, G.; Nigussie-Dechassa, R.; Kebede, W.; Getachew, T.; Sharma, J. Growth and Nutrients Content and Uptake of Garlic (Allium sativum L.) as Influenced by Different Types of Fertilizers and Soils. Sci. Technol. Arts Res. J. 2013, 2, 35. [CrossRef]

42. Suthar, S. Impact of vermicompost and composted farmyard manure on growth and yield of garlic (Allium stivum L.) field crop. Int. J. Plant Prod. 2009, 3, 27-38.

43. Alemu, D.; Nigussie, D.; Fikreyohannes, G. Effect of vermicompost and inorganic NP fertilizers on growth, yield and quality of Garlic (Allium sativum L.) in Enebse Sar Midir District, Northwestern Ethiopia. J. Biol. Agric. Healthc. 2016, 6, 57-75.

44. Orłowski, M.; Rekowska, E.; Dobromilska, R. The effect on the yield of garlic (Allium sativum L.) of autumn and spring planting using different methods of seed-stalk trimming. Folia Hortic. 1994, 2, 79-89.

45. Majkowska-Gadomska, J.; Wierzbicka, B. The effect of weather conditions on the yield of common Garlic. Ann. Univ. Mariae Curie-Skłodowska Lub.-Pol. 2006, 16, 55-61.

46. Barker, A.V.; Pilbeam, D.J. Handbook of Plant Nutrition; Taylor and Francis: Boca Raton, FA, USA; London, UK; New York, NY, USA, 2007; pp. 17-64.

47. Liu, S.; He, H.; Feng, G.; Chen, Q. Effect of nitrogen and sulfur interaction on growth and pungency of different pseudostem types of Chinese spring onion (Allium fistulosum L.). Sci. Hortic. 2009, 121, 12-18. [CrossRef] 
48. Coolong, T.W.; Randle, W.M. Sulfur and Nitrogen Availability Interact to Affect the Flavor Biosynthetic Pathway in Onion. J. Am. Soc. Hortic. Sci. 2003, 128, 776-783. [CrossRef]

49. Rizk, F.A.; Shaheen, A.M.; El-Samad, E.H.A.; Sawan, O.M. Effect of different nitrogen plus phosphorus and sulphur fertilizer levels on growth, yield and quality of onion (AIlium cepa L.). J. Appl. Sci. Res. 2012, 8, 3353-3361.

50. Bull, L.T.; Costa, M.C.G.; Novello, A.; Fernandes, D.M.; Bôas, R.L.V. Doses and forms of application of phosphorus in vernalized garlic. Sci. Agric. 2004, 61, 516-521. [CrossRef]

51. Vadalà, R.; Mottese, A.F.; Bua, G.D.; Salvo, A.; Mallamace, D.; Corsaro, C.; Vasi, S.; Giofrè, S.V.; Alfa, M.; Cicero, N.; et al. Statistical Analysis of Mineral Concentration for the Geographic Identification of Garlic Samples from Sicily (Italy), Tunisia and Spain. Foods 2016, 5, 20. [CrossRef]

52. Mengel, K.; Kirkby, E.A. Principles of Plant Nutrition, 5th ed.; Kluwer Academic Publishers: Dordrecht, The Netherlands, 2001; p. 849.

53. Prabhu, A.S.; Fageria, N.K.; Huber, D.M.; Rodrigues, F.A. Potassium and plant disease. In Mineral Nutrition and Plant Disease; Datnoff, L.E., Elmer, W.H., Huber, D.M., Eds.; The American Phytopathological Society: St. Paul, MN, USA, 2007; pp. 57-78.

54. Diriba-Shiferaw, G.; Nigussie-Dechassa, R.; Kebede, W.; Tabor, G.; Sharma, J.J. Bulb quality of Garlic (Allium sativum L.) as influenced by the application of inorganic fertilizers. Afr. J. Agric. Res. 2014, 9, 784-796. [CrossRef]

55. Yoldas, F.; Ceylan, S.; Mordogan, N.; Esetlili, B.C. Effect of organic and inorganic fertilizers on yield and mineral content of onion (Allium cepa L.). Afr. J. Biotechnol. 2011, 10, 11488-11492. [CrossRef] 